\title{
Treating Simulated Nitrate Pollution Groundwater with Different pH by Microbial Fuel Cell
}

\author{
Shaohua Chen ${ }^{1 *}$, Wenliang Chen ${ }^{1}$, Xiufang Wang ${ }^{1}$, Yi Ding ${ }^{1}$, \\ Donglin Zhao', Jiaquan Wang ${ }^{2}$ \\ ${ }^{1}$ School of Materials Science and Chemical Engineering, Anhui Jianzhu University, \\ Hefei 230022, Anhui Province, P.R. China \\ ${ }^{2}$ School of Resource and Environment Engineering, Hefei University of Technology, \\ Hefei 230009, Anhui Province, P.R. China
}

Received: 23 December 2019

Accepted: 24 February 2020

\begin{abstract}
Microbial fuel cell (MFC) is regarded as a promising technology to treat waste water and generate electricity simultaneously. MFCs usually work in the water-soluble medium, but the performance of the MFC which works in the porous medium is still unclear. Therefore, in this paper, a sand box was used to construct a dual-chamber MFC to investigate its performance. The MFC was used in porous medium to simulate the environment of groundwater, which was used to investigate the nitrate removal rate and the performance of electricity generation under different $\mathrm{pH}$ values. The performance of the MFC electrode was investigated by cyclic voltammetry (CV) and electrochemical impedance spectroscopy (EIS). The results showed that the maximum power density was $0.003 \mathrm{~mW} / \mathrm{m}^{3}(\mathrm{pH}=7.0)$ and the lowest nitrate concentration was $0.49 \mathrm{mg} / \mathrm{L}(\mathrm{pH}=8.5)$. The dominant microbial communities were Comamonadaceae bacterium, Xanthomonas axonopodis et al. Although the MFC was weak in electricity generation, it could offer valuable reference to further experiment.
\end{abstract}

Keywords: porous medium, groundwater, nitrate, different $\mathrm{pH}$ values, microbial fuel cell (MFC)

\section{Introduction}

With the rapid development of social economy, groundwater pollution is becoming more and more serious [1-3]. Groundwater is one of the most important resources in the world. It is a source of agricultural irrigation and drinking water of people [4]. However, it has received high $\mathrm{N}$ input from fertilizers [5], livestock wastewater and urban landfill leachate $[6,7]$ up to

*e-mail: chshaohua@126.com now. Even if anthropogenic inputs of reactive nitrogen were stopped today, elevated nitrate concentrations in aquifers could persist for decades to centuries, sustaining eutrophication in rivers, lakes, and estuaries $[8,9]$. The government has to spend billions of dollars in environmental governance. The high concentration of nitrate in the groundwater will cause a series of diseases, such as colorectal cancer and non-Hodgkin lymphoma [10-12]. It also can affect local precipitation and cause climate degradation [13]. Therefore, nitrate removal is becoming the main issue to be solved [14, 15]. Many water quality assessment models have been used to assess the water quality, such as water quality 
index [16]. For the groundwater, Maryam Hosseini suggested that modified DRASTIC and GODS models can be used to assess groundwater vulnerability to pollution [17]. These models intuitively describe the degree of water pollution.

Microbial fuel cell (MFC), as a promising device to use bacteria as the catalysts to oxidize organic and inorganic matter and generate current, has been focused by a number of researchers. Ye Y. [18], Adeniran J.A. [19] and Zhu T.T. [20] constructed a dual-compartment MFC to treat wastewater under different ammonium concentrations. Nayak et al [21] prepared H-type two-chamber MFC by using sewage wastewater and distillery wastewater to investigate its efficiency. Zhu G.C. et al. [22] and Jin X.J. et al. [23] constructed a multi-anode MFC and an anodic denitrifying MFC respectively to investigate simultaneous nitrification and denitrifaction with different $\mathrm{C} / \mathrm{N}$ ratios. Vilajeliu-Pons A. [24] designed a stacked MFC to treat swine manure with different electrode materials. Oon Y.S. [25] and Zhu G. C. [26] studied the denitrification and electricity generation capacity of MFC in closed or open circuit. These researches explored various factors affecting the performance of the MFCs treating nitrogen-containing wastewater. Their conclusions provide theoretical basis and practical reference for actual application of MFCs.

However, current studies are mostly limited to small water-soluble medium system MFCs, and their conclusions are not necessarily applicable to porous medium system of groundwater. The environment of groundwater is very complex. The temperature and $\mathrm{pH}$ are greatly different from district to district. For example, the temperature of groundwater keeps at $6.5-9.5^{\circ} \mathrm{C}$ in the north of China while keeps at $9-12^{\circ} \mathrm{C}$ in the northwest of China. The $\mathrm{pH}$ of groundwater in southern China is generally lower than that in northern China. The harsh environment of groundwater limits the growth of microorganisms.

In this study, we constructed a large-volume porous medium system MFCs whose anode and cathode were made of carbon cloth. We used a sand tanker to simulate the environment of groundwater. Under different $\mathrm{pH}$ values, we analysed the degradation degree of COD and nitrate. At optimal $\mathrm{pH}$ value, cyclic voltammetry and EIS were used to determine the best power generation capacity of MFC and DGGE was used to analyse the microbial community. The results of this paper can be used for further study.

\section{Material and Methods}

\section{Constructional Idea of Large-Volume Dual-Chamber MFC Device}

Most of the experimentally studied MFC devices used PEM to conduct protons between the anode and cathode chambers at present. However, the expensive price and inconvenient use of PEM, which need cleaning after a period of time, inevitably limits its actual development and application. Salt bridge has great advantages in practical applications for its inexpensive price and easy operation. Therefore, this paper used salt bridge as the spacing material of the anode and cathode chamber to transfer protons and combined the actual conditions of the treated groundwater to design the dual-chamber in-situ remediation MFC device.

The electron transfer in the environment of groundwater is complex. The electron transfer rate in porous system is lower than that in water-soluble system. To investigate the effect of porous system, we constructed a sand tanker as cathode chamber. The permeability of the sand was $0.0015 \mathrm{~cm} / \mathrm{s}$ and the inlet flux was $8.85 \mathrm{~mL} / \mathrm{min}$.

\section{Constructional Method of Large-Volume Dual-Chamber MFC Device}

Dual-chamber MFC is applied to treating polluted groundwater. The cathode chamber of MFC is usually placed in the underground aquifer. Each cathode chamber of this paper is similar to a single well with the

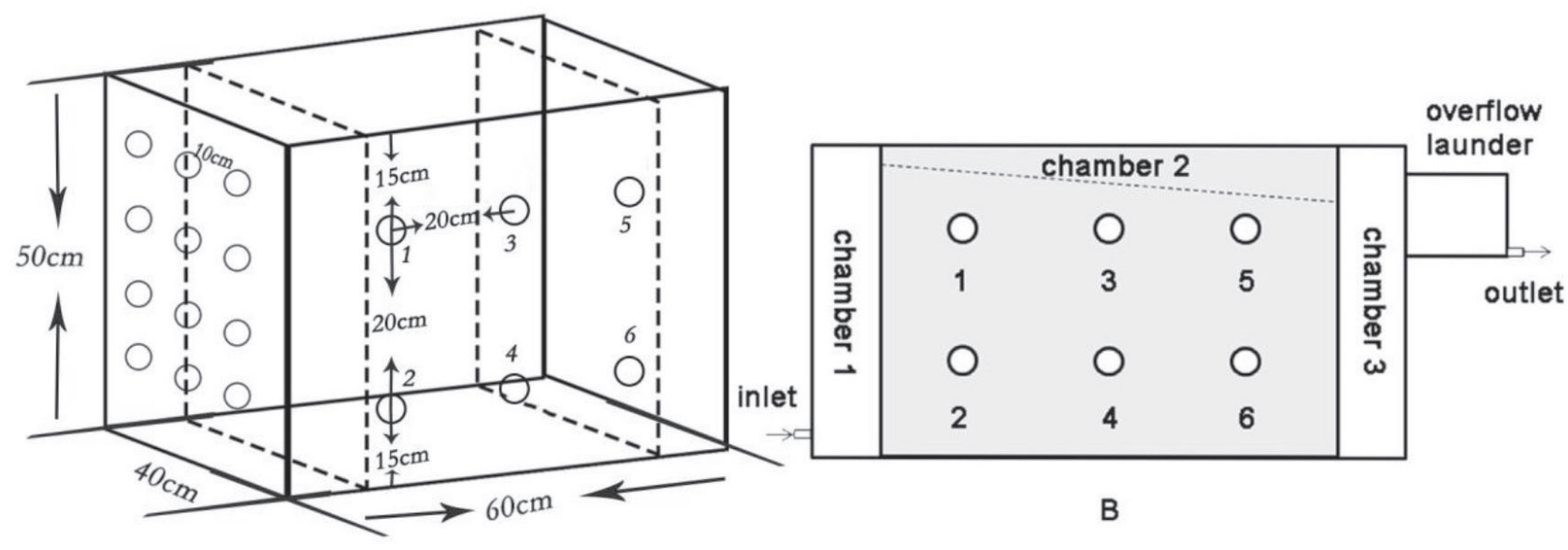

Fig. 1. Sketch map of the large-volume dual-chamber MFC device. 




Fig. 2 physical map of the large-volume dual-chamber MFC device.

same salt bridge and carbon cloth electrode. The cathode chamber was filled with sand, and the anode chamber was filled with solution. The salt bridge of each cathode chamber was connected to anode chamber. The anode chamber was sealed by a cover, and the cover had a corresponding number of holes according to the number of salt bridges. Therefore, each cathode chamber and an anode chamber could form a circuit through the salt bridge.

Five cathode chambers (net volume was $0.5 \mathrm{~L}$ per chamber) were arranged in the sand tanker according to quincunx arrangement in this paper. There were six holes on the sand tanker. The upper three were hole 1 , 3 , and 5. The lower three were hole 2, 4, and 6. Salt bridge was made of plastic hose which was injected with molten AGAR and $\mathrm{KCl}$, and the pipe diameter and length of the plastic hose were $1.5 \mathrm{~cm}$ and $55 \mathrm{~cm}$ respectively. The area of carbon cloth cathode was $120 \mathrm{~cm}^{2}\left(12 \times 10 \mathrm{~cm}^{2}\right)$. The net volume of the anode chamber which was made of organic glass was $9000 \mathrm{~cm}^{3}\left(30 \times 15 \times 20 \mathrm{~cm}^{3}\right)$, and the area of the carbon cloth anode was $176 \mathrm{~cm}^{2}$. Fig. 1 and Fig. 2 are the sketch map and physical map of the large-volume dual-chamber MFC device respectively. The connection method of the salt bridge shown in Fig. 1 used a main bridge. Considering the small treated area in practice and easy operation, the salt bridges were directly placed in the solution of the anode chamber.

\section{Detection and Analysis Method of Large-Volume Dual-Chamber MFC Device}

Analytical methods of nitrate pollutants in water:

- Ultraviolet spectrophotometry method is used to measure $\mathrm{NO}_{3}^{-}-\mathrm{N}$,

- N-(1-naphthyl)-ethylenediamine spectrophotometry method is used to measure $\mathrm{NO}_{2}^{-}-\mathrm{N}$,

- Nessler reagent spectrophotometric method is used to measure $\mathrm{NO}_{4}^{+}-\mathrm{N}$, and $\mathrm{COD}$ closed fast digestion titration method is used to measure COD.
The electricity generation performance of MFC was characterized by output voltage, internal resistance, polarization curve, and power density curve. In this experiment, the output voltage of MFC was continuously monitored by a real-time voltage monitor (PCI1713 data acquisition card, Taiwan Yanhua Science and Technology Company). The data were automatically stored by software in the computer, and the frequency of data recording was $400 \mathrm{~s} /$ times. The current produced by MFC can be calculated by Ohm's law: $\mathrm{I}=\mathrm{U} / \mathrm{R}$, in which $\mathrm{U}$ is the output voltage of MFC and $\mathrm{R}$ is the resistance of the external circuit. Polarization curve reflects the relationship between electrode potential and polarization current. In this experiment, the MFC polarization curve [27] was measured by steady-state discharge method. Coulomb efficiency (CE) is calculated by formula [28]. EIS is applied to evaluate the catalytic activity of the electrode and was measured by CHI-660C equipment (Shanghai Chenhua electrochemical instrument Co., Ltd). Microbial community is characterized by SEM-EOL JSM-6390LA scanning electron microscope (Japan Electronics Company) and DGGE (Bio-Rad Company, USA).

$\mathrm{pH}$ value is one of the most important factors affecting MFC performance. In this paper, three groups of experiments were designed to control the $\mathrm{pH}$ value of the solution to be 5.5, 7.0 and 8.5 respectively. The concentrations of nitrate and COD in the three solutions were $100 \mathrm{mg} / \mathrm{L}$ and $500 \mathrm{mg} / \mathrm{L}$ respectively, and the external resistance of the battery was $1000 \Omega$. The experimental conditions, methods, monitoring indexes and sampling intervals of the three comparative groups are the same. The samples were taken every 4 hours from each outlet and were taken 4 times a day. To evaluate the MFCs capacity of continuous decontamination and electricity generation, the running time is 120 hours.

The research methodology diagram is presented in Fig. 3.

\section{Results and Discussion}

\section{COD Removal of Dual-Chamber MFC under Different $\mathrm{pH}$ Values}

Fig. 4 showed the condition of COD removal under three different $\mathrm{pH}$ values of the anode solution in dual-chamber MFC devices. As shown in Fig. 4, the $\mathrm{pH}$ values had a great influence on COD removal in the dual-chamber MFC device. The MFCs whose $\mathrm{pH}$ values were 5.5 and 7.0 still showed the performance of decontamination, while the COD basically didn't degrade in the MFC whose $\mathrm{pH}$ was 8.5 in the running time of experiment, where the lowest COD concentration was $365 \mathrm{mg} / \mathrm{L}$ and even up to $575 \mathrm{mg} / \mathrm{L}$ at the end of experiment. It showed that COD had accumulated a lot in it. By comparison, the MFC whose $\mathrm{pH}$ value was 7.0 had better performance in two aspects: first, the 


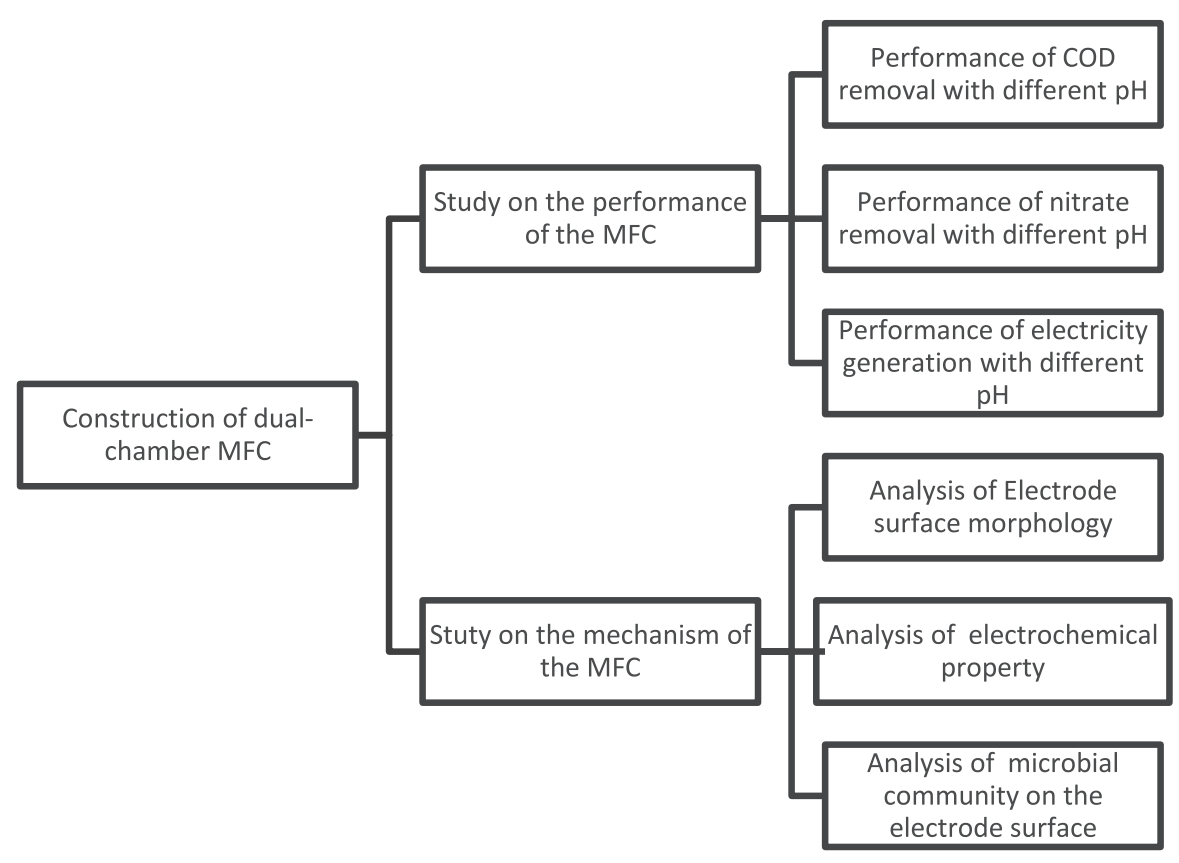

Fig. 3. research methodology flowchart.

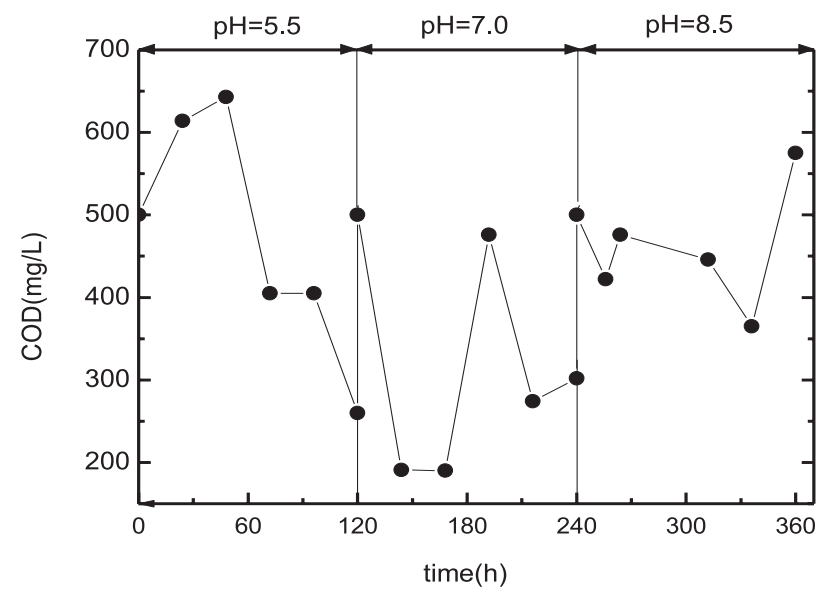

Fig. 4. COD removal under different $\mathrm{pH}$ values.

lowest COD concentration in the anode solution was $190 \mathrm{mg} / \mathrm{L}$, while the lowest COD concentration in the MFC anode solution whose $\mathrm{pH}$ value was 5.5 was $260 \mathrm{mg} / \mathrm{L}$; second, the degradation efficiency was higher than that of the MFC whose $\mathrm{pH}$ value is 5.5 except for the third day. The results showed that the double chamber device is more suitable for treating neutral polluted groundwater.

\section{Nitrate Removal of Dual-Chamber MFC under Different $\mathrm{pH}$ Values}

The variation curves of the three nitrogen concentrations of the dual-chamber MFC's outlets under different $\mathrm{pH}$ values were shown in Fig. 5 and Fig. 6 respectively. The nitrate degradation values of the overflow tank outlet were shown in Fig. 7.
As shown, the nitrate removal efficiency was different under different $\mathrm{pH}$ values. Nitrate concentrations of hole $1,2,3$, and 4 were high under different $\mathrm{pH}$ values, and their concentrations decreased on the first day, while their concentrations kept at a high level at other time. Nitrate concentration of hole 5 was high at $\mathrm{pH}$ of 7.0 , while nitrate concentration of hole 5 rapidly decreased at $\mathrm{pH}$ of 5.5 and 8.5 on the first day of equipment running, and the lowest concentrations were $3.18 \mathrm{mg} / \mathrm{L}$ and $0.49 \mathrm{mg} / \mathrm{L}$ respectively. However, they increased again from the next day. Nitrate concentration of hole 6 continuously decreased at $\mathrm{pH}$ of 7.0, which performed better than that at $\mathrm{pH}$ of 5.5 and 8.5. The value of the final overflow tank outlet indicates that the MFC at $\mathrm{pH}$ of 7.0 had a slightly better final performance, and the value kept at a lower level from the next day of the experiment. The lowest concentration was $19.51 \mathrm{mg} / \mathrm{L}$, but then increased again. The end value was $73.77 \mathrm{mg} / \mathrm{L}$. The result showed the instability of the device in the degradation of nitrate. Nitrate concentration generally over $70 \mathrm{mg} / \mathrm{L}$ except individual date at $\mathrm{pH}$ of 5.5 and 8.5. Fig. 5 to Fig. 7 reflected the relationship between the variation of nitrate concentration and spatiotemporal variation. Although the average value of the lower three holes was lower than that of the upper three holes, the overall values were high. Nitrate was worse for degradation under acidic and alkaline conditions than that under neutral condition. This result was consistent with the finding of other researchers [29, 30]. In neutral condition, the activity of the microorganism were better, which could accelerate redox reaction for nitrate. In acidic or alkaline, the activity of microorganism were inhibited. 
a)



b)

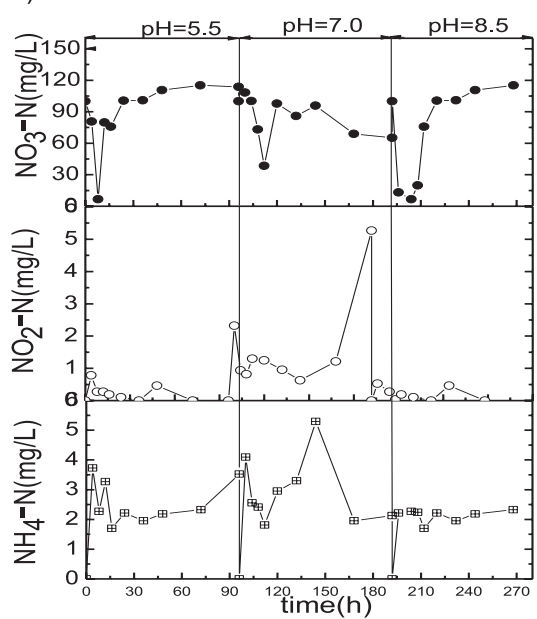

c)

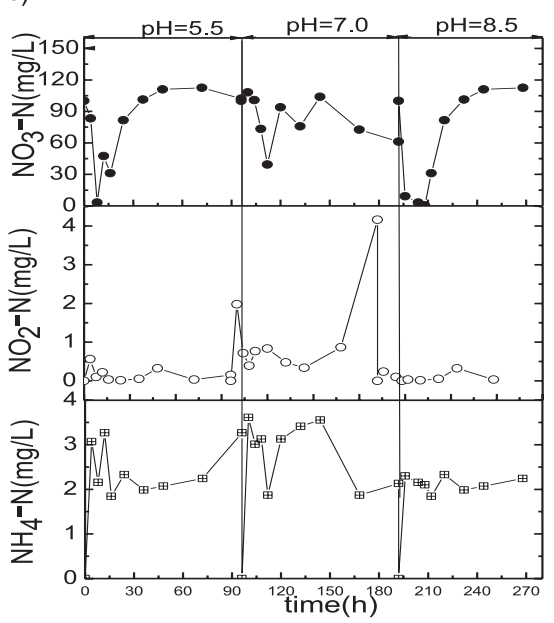

Fig. 5. a) variation curve of nitride concentration of hole 1 under different $\mathrm{pH}$ values; b) variation curve of nitride concentration of hole 3 under different $\mathrm{pH}$ values; $\mathrm{c}$ ) variation curve of nitride concentration of hole 5 under different $\mathrm{pH}$ values.

a)

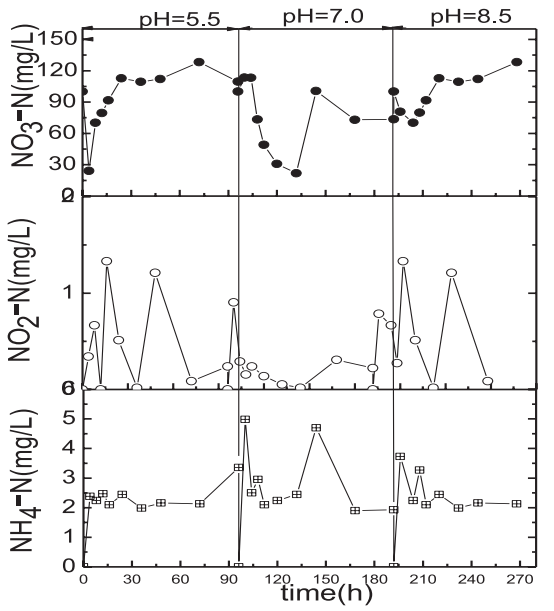

b)

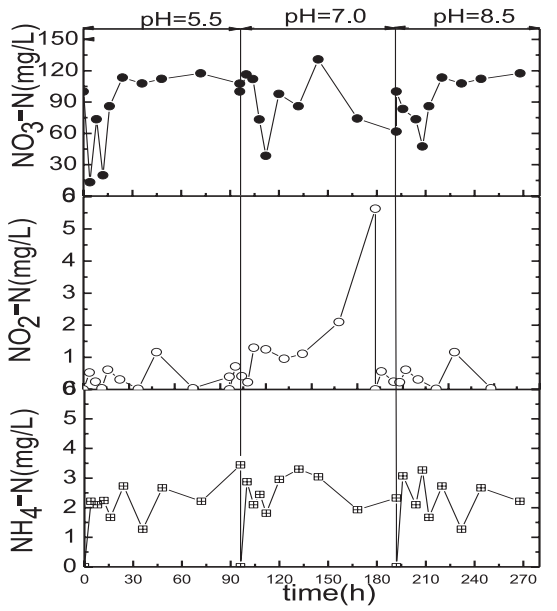

c)

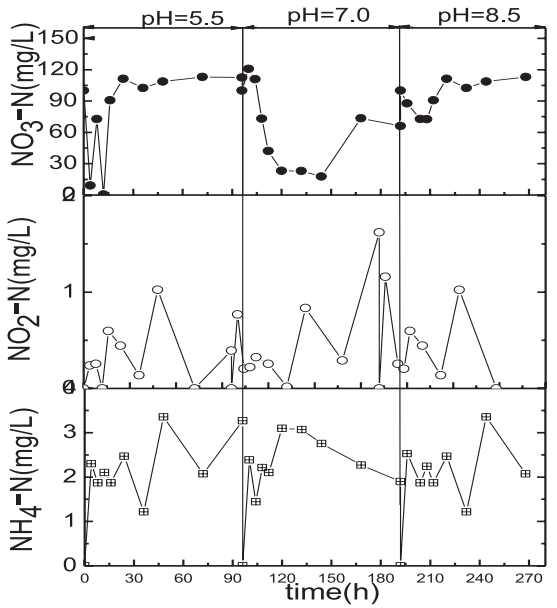

Fig. 6. a) variation curve of nitride concentration of hole 2 under different $\mathrm{pH}$ values; b) variation curve of nitride concentration of hole 4 under different $\mathrm{pH}$ values; c) variation curve of nitride concentration of hole 6 under different $\mathrm{pH}$ values.

\section{The Electricity Generation Performance under Different $\mathrm{pH}$ Values}

The electricity generation curve of dual-chamber MFC under different $\mathrm{pH}$ values showed in Fig. 8, and the corresponding polarization curve and power density curve showed in Fig. 9.

As shown in Fig. 8, at the $\mathrm{pH}=7.0$, the voltage was small and basically kept at about $40 \mathrm{mV}$. The highest voltage was $70.8 \mathrm{mV}$. At the $\mathrm{pH}=8.5$, the voltage continuously increased to $130 \mathrm{mV}$ after 12 hours and then kept constant for 13 hours. After that, it started to decrease. At the $\mathrm{pH}=5.5$, the MFC barely generated electricity.

As shown in Fig. 9, the optimum internal resistance of the MFC whose $\mathrm{pH}$ was 7.0 was $12000 \Omega$, the maximum power density was $0.003 \mathrm{~mW} / \mathrm{m}^{2}$, the corresponding current density was $0.12 \mathrm{~mA} / \mathrm{m}^{2}$. The optimum internal resistance of the MFC whose $\mathrm{pH}$ is 8.5 was $9000 \Omega$, the maximum power density was $0.00316 \mathrm{~mW} / \mathrm{m}^{2}$, the corresponding current density was $0.141 \mathrm{~mA} / \mathrm{m}^{2}$. The optimum internal resistance of the MFC whose $\mathrm{pH}$ is 5.5 was $12000 \Omega$, the maximum power density was $0.00159 \mathrm{~mW} / \mathrm{m}^{2}$, the corresponding current density was $0.087 \mathrm{~mA} / \mathrm{m}^{2}$.

Compared with other researchers, the above results showed that the power generation performance of the dual-chamber MFC device under three different $\mathrm{pH}$ environments had not been properly exerted (Table 1). The reason may be related to salt bridge, porous medium system and running time. They greatly increased the internal resistance and decreased the electron transfer rate [31,32]. At neutral condition, it was not suitable for bacterial to generate electricity. However, the other researchers constructed a small single-chamber MFC, and the anode and the cathode 


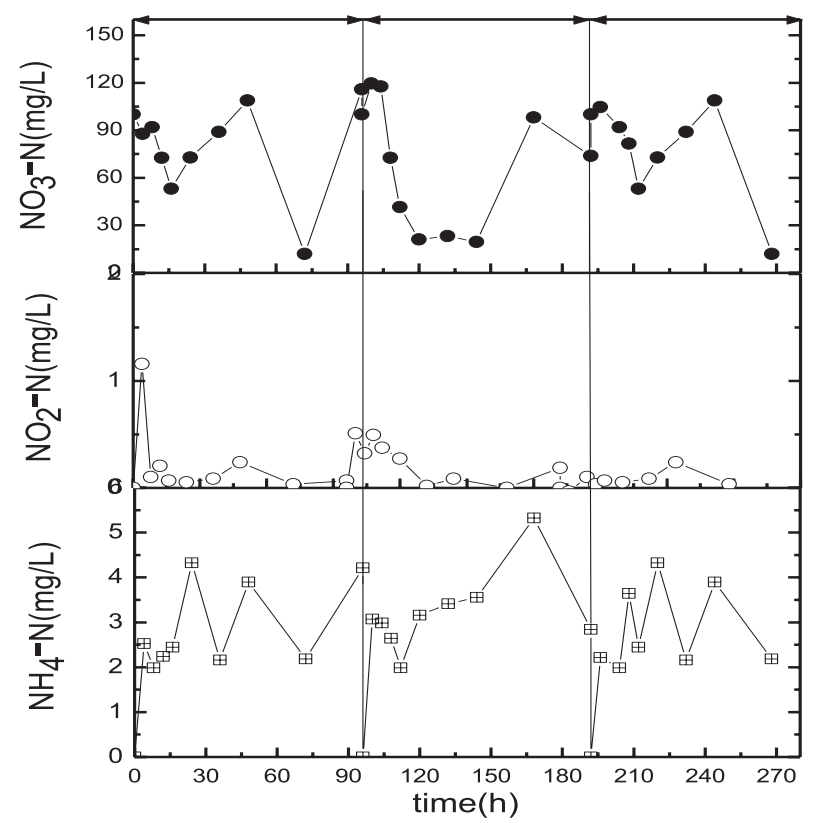

Fig. 7. variation curve of nitride concentration of the overflow tanker outlet under different $\mathrm{pH}$ values.

were closer, which improved the electrode transfer rate.

\section{Electrochemical Activity Research in the Dual-Chamber MFC Device}

Using cyclic voltammetry (CV) and electrochemical impedance spectroscopy (EIS) to test the electrodes of the mid-experiment and the end of the experiment. The anode and the cathode solutions were sampled at the mid-experiment and the end of the experiment.

\section{Cyclic Voltammetry (CV) Analysis}

$\mathrm{CV}$ curves of the carbon cloth cathode which obtained at the mid-term experimental solution and

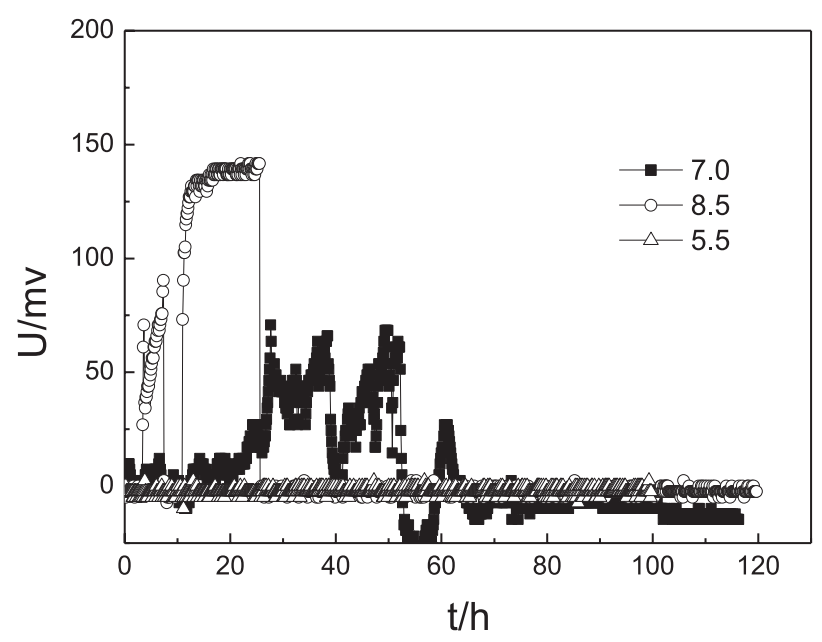

Fig. 8. voltage curve under different $\mathrm{pH}$ values.



Fig. 9. curves of the maximum power density and polarization under different $\mathrm{pH}$ values.

the end experimental solution showed in the Fig. 10a). $\mathrm{CV}$ curves of the carbon cloth anode which obtained at the mid-term experimental solution and the end experimental solution showed in the Fig. 10b).

As shown in Fig. 9a), the CV curves of the carbon cloth cathode were smooth in the two solutions, and we couldn't observe the redox peak during the whole cyclic scanning process. It meant that the redox reaction didn't occur on the cathode. The values of the current and voltage had the same order of magnitude at the midexperiment and the end of the experiment.

As shown in Fig. 10b), the electrochemical activity of the anode varied greatly with the running time of the reaction. We couldn't observe the redox peak of the anode of the mid-experiment on CV curve, and the range of the current variation was narrow, which indicated that the electrochemical activity was poor. However, an obvious oxidation peak of the anode of the end of the experiment appeared at $-0.83 \mathrm{~V}$ on the $\mathrm{CV}$ curve, and the range of the current variation enlarged. It meant that the electrochemical activity increased with prolonging the time of reaction.

By observation, there were few biofilms on the surface of the cathode, while there were many biofilms on the surface of the anode, which led to the different shape of the CV curves. It also meant that the microorganism produced electrons while consuming carbon source by respiration, resulting in the electrons accumulated near the electrode, which influenced the electrochemical activity of the electrode. The mechanism could be as follows:

$$
\begin{gathered}
2 \mathrm{NO}_{3}^{-}+4 \mathrm{H}^{+}+4 e^{-} \rightarrow 2 \mathrm{NO}_{2}^{-}+2 \mathrm{H}_{2} \mathrm{O} \\
2 \mathrm{NO}_{2}^{-}+4 \mathrm{H}^{+}+2 e^{-} \rightarrow 2 \mathrm{NO}+2 \mathrm{H}_{2} \mathrm{O} \\
2 \mathrm{NO}+2 \mathrm{H}^{+}+2 e^{-} \rightarrow \mathrm{N}_{2} \mathrm{O}+\mathrm{H}_{2} \mathrm{O} \\
\mathrm{N}_{2} \mathrm{O}+2 \mathrm{H}^{+}+2 e^{-} \rightarrow \mathrm{N}_{2}+\mathrm{H}_{2} \mathrm{O}
\end{gathered}
$$


Table 1 Maximum power and maximum current obtained when treating nitrogen-containing wastewater.

\begin{tabular}{|c|c|c|c|c|}
\hline Methods & Medium & Maximum power & Maximum current & Reference \\
\hline CWs-MFC & Swine slurry \& alum sludge & $0.268 \mathrm{~W} / \mathrm{m}^{3}$ & $0.9 \mathrm{~A} / \mathrm{m}^{3}$ & {$[33]$} \\
\hline CWs-MFC & Wastewater \& gravel & $36 \mathrm{~mW} / \mathrm{m}^{2}$ & $219 \mathrm{~mA} / \mathrm{m}^{2}$ & {$[34]$} \\
\hline CWs-MFC & Swine slurry, gravel \& alum sludge & $0.276 \mathrm{~W} / \mathrm{m}^{3}$ & $0.636 \mathrm{~A} / \mathrm{m}^{3}$ & {$[35]$} \\
\hline
\end{tabular}

\section{Electrochemical Impedance Spectroscopy (EIS) Analysis}

Using the EIS to test the anode of the midexperiment and the end of the experiment, and the electrochemical impedance spectrogram showed as Fig. 11.

As shown in Fig. 11, a capacitive arc appeared between 26500-27800 $\Omega$ at the end of the experiment, while a capacitive arc appeared between $27250-28500 \Omega$ at the mid-experiment. The capacitive arc radius of the end of the experiment was smaller. The value of charge-transfer resistance depends on the capacitive arc radius. The smaller the radius of the capacitive reactance arc was, the smaller the impedance value was, and the electrode surface polarization resistance was smaller. Therefore the electrochemical activity of the anode at the end of the experiment increased. The conclusion was consistence with cyclic voltammetry.
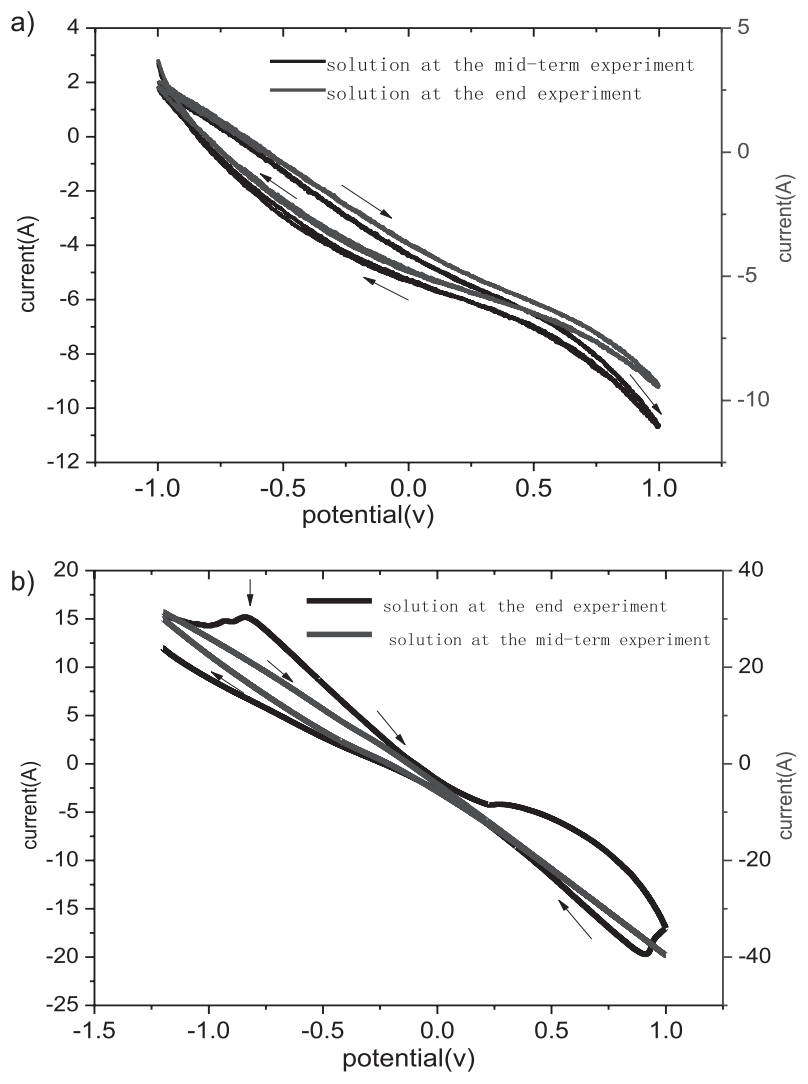

Fig. 10. a) CV curve of the anode; b) CV curve of the cathode.

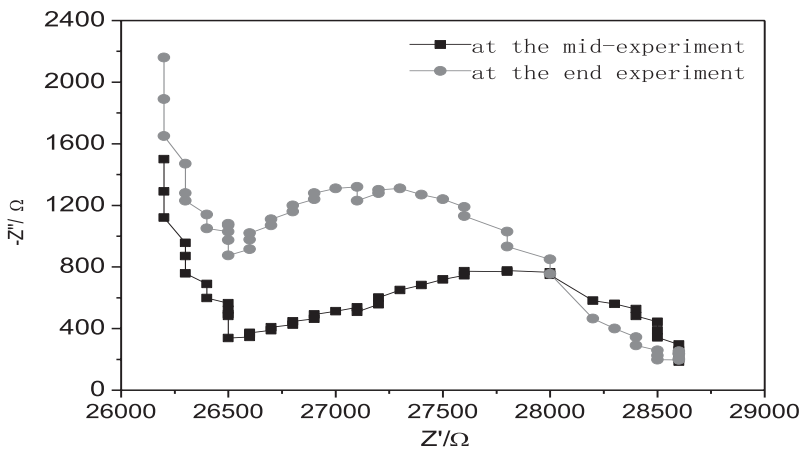

Fig. 11. EIS atlas of the anode solution.

\section{Microbial Community Analysis \\ Morphological Analysis of Biofilm on Electrodes Surface}

The surface morphology of the carbon cloth anode and cathode after the end of the experiment was observed by SEM, and the results are shown in Fig. 12. Fig. 12a) clearly showed that a thick layer of rod-shape bacteria attached to the surface of the anode. Fig. 12b) showed that only few rod-shaped bacteria attached to the surface of the cathode. This was closely related to the fact that the anode and cathode were in different systems. Although the anode and the cathode had been used for two months, and the anode and cathode solution was inoculated with the same activated sludge, the carbon cloth anode was placed in solution medium system, and the carbon cloth cathode was placed in porous medium system. At the same time, there was adequate carbon resource in the anode chamber. Therefore, there was an obvious difference in biofilm on the anode and the cathode, which directly caused the differences between the electrochemical activity of the two electrodes.

\section{Analysis of Microbial Community Composition on Electrodes Surface}

DNA was extracted from the biofilm samples on the anode surface at the end of the experiment and was carried out PCR amplification and DGGE electrophoresis. The gene fragments of the dominant bacteria in the biofilm were shown in Fig. 13. Each bright band in the picture represented a bacterial species, and the brightness indicated the relative 
a)

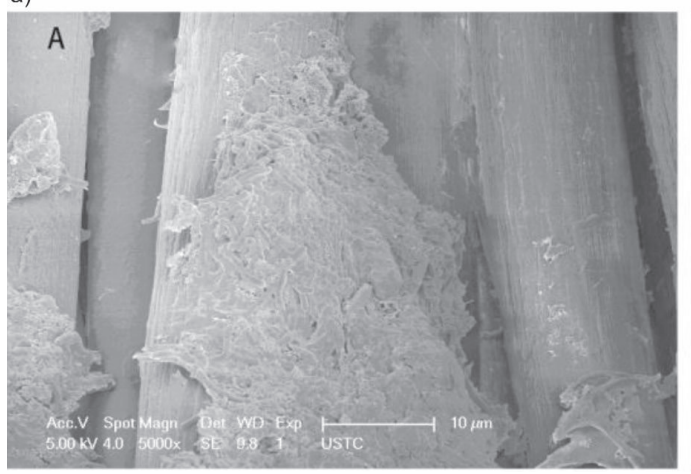

b)

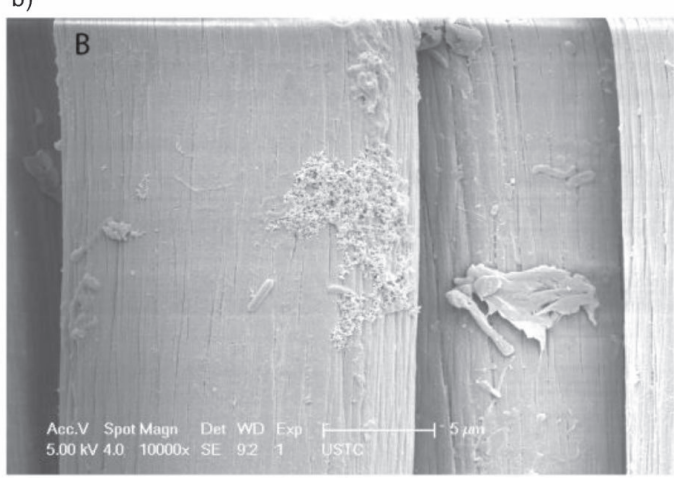

Fig. 12. a) the carbon cloth anode; b) the carbon cloth cathode.

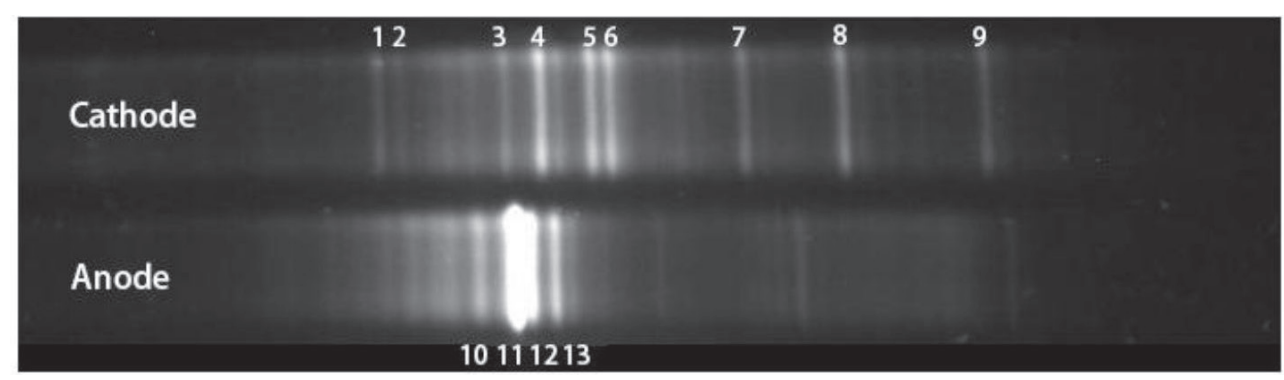

Fig. 13. DGGE image of biofilm bacteria on the carbon cloth anode.

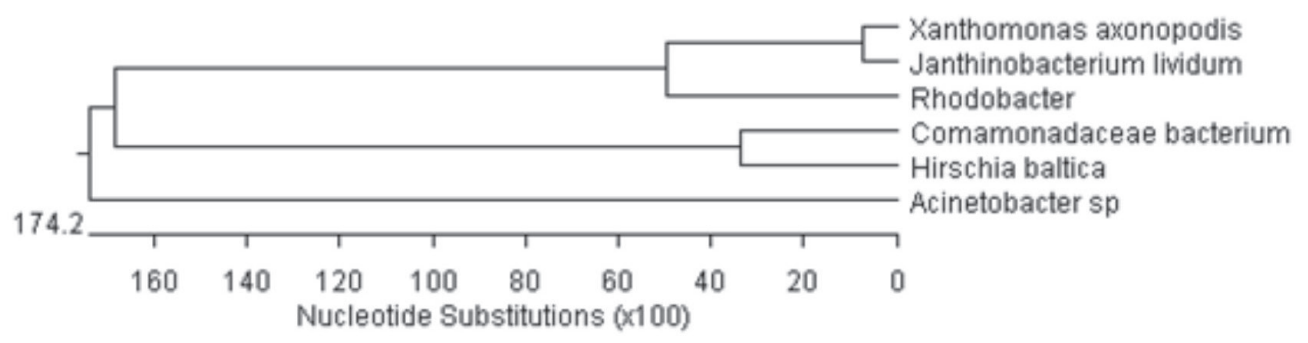

Fig. 14. Eevolution tree of bacteria community in dual-chamber.

abundance of the bacteria in the community. The Brightness-enhanced bands 4, 5, 6, 10, 11 and 12, which the electrodes mutually had, were separated from DGGE gel, sequenced after PCR amplification, and the measured gene sequences were submitted to the gene bank of the National Biotechnology Information
Center of the United States. The corresponding login numbers were obtained, and the sequences with higher similarity were aligned as shown in Table 2, respectively. Sequences can be found in the gene pool, and the highest similarity is $100 \%$. DNA Star software was used to make the evolutionary tree of strains that

Table 2 DNA sequencing results of biofilm on dual-chamber carbon cloth anode and cathode, and compared with Genbank Database.

\begin{tabular}{|c|c|c|c|}
\hline Sequence designation & Accession number & The results of Ribosomal database project & Identity (\%) \\
\hline Band4 & AJ505857 & Comamonadaceae bacterium & 76 \\
\hline Band5 & AB101445 & Xanthomonas axonopodis & 100 \\
\hline Band6 & AF234745 & Rhodobacter & 100 \\
\hline Band10 & GQ497287 & Janthinobacterium lividum & 89 \\
\hline Band11 & AB021388 & Hyphomicrobium sp & 96 \\
\hline Band12 & HM124367 & & \\
\hline
\end{tabular}


were selected with high similarity and identified by adjacency method. The results were shown in Fig. 14. It could be seen from the evolutionary tree that the biofilm bacteria on the cathode and anode carbon cloth had high homology of Rhodobacter, Acinetobacter sp, Hyphomicrobium sp, respectively. The dominant microbial communities attached to carbon cloth electrodes were Comamonadaceae bacterium, Xanthomonas axonopodis, Rhodobacter, Hyphomicrobium sp, Acinetobacter sp, Janthinobacterium lividum and Hyphomicrobium sp.

\section{Conclusions}

This study constructed a dual-chamber MFC to treat nitrogen-containing groundwater, and the MFC worked in the porous medium which was used to simulate the environment of groundwater. The highest COD removal efficiency was $62 \%\left(\frac{500-190}{500} \mathrm{mg} / \mathrm{L}=62 \%\right)$, and the maximum power density was $0.003 \mathrm{~mW} / \mathrm{m}^{2}$. The high COD removal efficiency meant that the MFC could be used to treat groundwater in practice. In the porous medium, there were few microorganism attach to the cathode while there were many microorganism attach to the anode in the water-soluble medium. That was the reason why the property of anode better than that of cathode. The domain microbial communities were Comamonadaceae bacterium, Xanthomonas axonopodis, Rhodobacter, Hyphomicrobium sp, Acinetobacter sp, Janthinobacterium lividum and Hyphomicrobium sp. Though the ability of electricity generation was weak, it could be improved by improving the structure of MFC. This result can be used for reference for our further study.

\section{Acknowledgements}

This work was supported by the National Natural Science Foundation of China (No. 41372246), the Anhui Province Key Research and Development Project (1704g07020113), and Major Special Projects of Science and Technology of Anhui Province (201903a07020002).

\section{Conflicts of Interest}

The authors declare no conflict of interest.

\section{References}

1. AHAMAD A., MADHAV S., SINGH P., PANDEY J., KHAN A.H. Assessment of groundwater quality with special emphasis on nitrate contamination in parts of Varanasi City, Uttar Pradesh, India. Appl. Water Sci. 8 (4), 1, 2018. https://doi.org/10.1007/s13201-018-0759-x

2. AGARWAL M., SINGH M., HUSSAIN J. Assessment of groundwater quality with special emphasis on nitrate contamination in parts of Gautam Budh Nagar district, Uttar Pradesh, India. Acta Geochim. 38 (5), 703. 2019. https://doi.org/10.1007/s11631-018-00311-z.

3. STIGTER T.Y., CARVALHO DILL A.M.M., RIBEIRO L. Major issues regarding the efficiency of monitoring programs for nitrate contaminated groundwater. Environ. Sci. Technol. 45 (20), 8674, 2011. https://doi.org/10.1021/ es201798g.

4. BUROW K.R., NOLAN B.T., RUPERT M.G., DUBROVSKY N.M. Nitrate in groundwater of the United States, 1991-2003. Environ. Sci. Technol. 44 (13), 4988, 2010. https://doi.org/10.1021/es100546y.

5. HINSHAW S.E., ZHANG T., HARRISON J.A., DAHLGREN R.A. Excess $\mathrm{N}_{2}$ and denitrification in hyporheic porewaters and groundwaters of the San Joaquin River, California. Water Res. 168, 115161, 2020. https:/doi. org/10.1016/j.watres.2019.115161.

6. LEE K S., KO K.S., KIM E.Y. Application of stable isotopes and dissolved ions for monitoring landfill leachate contamination. Environ. Geochem. Health. 1, 2019. https:// doi.org/10.1007/s10653-019-00427-y.

7. KAUSHAL S.S., GROFFMAN P.M., BAND L.E., ELLIOTT E.M., SHIELDS C.A., KENDALL C. Tracking nonpoint source nitrogen pollution in human-impacted watersheds. Environ. Sci. Technol. 45 (19), 8225, 2011. https://doi.org/10.1021/es200779e.

8. GRUBER N., GALLOWAY J.N. An Earth-system perspective of the global nitrogen cycle. Nature. 451, 293, 2008. https://doi.org/10.1038/nature06592.

9. KOLBE T., DE DREUZY J.R., ABBOTT B.W., AQUILINA L., BABEY T., GREEN C.T., FLECKENSTEIN T., LABASQUE A.M., LAVERNMAN J., MARCAIS S., PEIFFER Z., THOMAS PINAY G. Stratification of reactivity determines nitrate removal in groundwater. Proc. Natl. Acad. Sci. U. S. A. 116 (7), 2494, 2019. https:// doi.org/10.1073/pnas.1816892116.

10. SCHULLEHNER J., HANSEN B., THYGESEN M., PEDERSEN C.B., SIGSGAARD T. Nitrate in drinking water and colorectal cancer risk: A nationwide populationbased cohort study. Int. J. Cancer. 143 (1), 73, 2018. https:// doi.org/10.1002/ijc.31306.

11. GULIS G., CZOMPOLYOVA M., CERHAN J.R. An ecologic study of nitrate in municipal drinking water and cancer incidence in Trnava District, Slovakia. Environ. Res. 88 (3), 182, 2002. https://doi.org/10.1006/ enrs.2002.4331.

12. HOWARTH R.W. Human acceleration of the nitrogen cycle: Drivers consequences, and steps toward solutions. Water Sci. Technol. 49 (5-6), 7, 2004. https://doi. org/10.2166/wst.2004.0731.

13. OBIANYO J.I., Effect of Salinity on Evaporation and the Water Cycle, Emerg. Sci. J. 3, 255-262, 2019. https://doi. org/10.28991/esj-2019-01188.

14. CASSMAN K.G., DOBERMANN A., WALTERS D.T. Agroecosystems, nitrogen-use efficiency, and nitrogen management. Ambio. 31 (2), 132, 2002. https://doi. org/10.1579/0044-7447-31.2.132.

15. HUNT N.D., HILL J.D., LIEBMAN M. Cropping system diversity effects on nutrient discharge, soil erosion, and agronomic performance. Environ. Sci. Technol. 53 (3), 1344, 2019. https://doi.org/10.1021/acs.est.8b02193.

16. MOHAMMED S.E., ADEL ABDULRAZZAQ K., Developing Water Quality Index to Assess the Quality of the Drinking Water, Civ. Eng. J. 4, 2345, 2018. https://doi. org/10.28991/cej-03091164. 
17. HOSSEINI M., SAREMI A. Assessment and Estimating Groundwater Vulnerability to Pollution Using a Modified DRASTIC and GODS Models (Case Study: Malayer Plain of Iran), Civ. Eng. J. 4, 433, 2018. https://doi.org/10.28991/ cej-0309103.

18. YE Y., NGO H.H., GUO W., CHANG S.W., NGUYEN D.D., LIU Y. NI, B., ZHANG X. Microbial fuel cell for nutrient recovery and electricity generation from municipal wastewater under different ammonium concentrations. Bioresour. Technol. 292, 121992, 2019. https://doi. org/10.1016/j.biortech.2019.121992.

19. ADENIRAN J.A., HUBERT R., DE-KOKER J.J., AROTIBA O.A., OLORUNDARE O.F., VAN-ZYL E., DU-PLESSIS S.C. Energy generation from domestic wastewater using sandwich dual-chamber microbial fuel cell with mesh current collector cathode. Int. J. Environ. Sci. Technol. 13 (9), 2209, 2016. https://doi.org/10.1007/ s13762-016-1050-z.

20. ZHU T.T., CAI W.W., WANG B., LIU W.Z., FENG K., DENG Y., WANG A.J. Enhanced nitrate removal in an Fe-driven autotrophic denitrification system using hydrogen-rich water. Environ. Sci.: Water Res. Technol. 5 (8), 1380, 2019. https://doi.org/10.1039/c9ew00423h.

21. NAYAK J.K., AMIT GHOSH U.K. An innovative mixotrophic approach of distillery spent wash with sewage wastewater for biodegradation and bioelectricity generation using microbial fuel cell. J. Water Process Eng. 23, 306, 2018. https://doi.org/10.1016/j.jwpe.2018.04.003.

22. ZHU G.C., HUANG S., LU Y.Z., GU X. Simultaneous nitrification and denitrification in the bio-cathode of a multi-anode microbial fuel cell. Environ. Technol. 1, 2019. https://doi.org/10.1080/09593330.2019.1663938.

23. JIN X.J., GUO F., MA W.Q., LIU Y., LIU H. Heterotrophic anodic denitrification improves carbon removal and electricity recovery efficiency in microbial fuel cells. Chem. Eng. J. 370, 527, 2019. https://oi.org/10.1016/j. cej.2019.03.023.

24. VILAJELIU-PONS A., PUIG S., SALCEDO-DÁVILA I., BALAGUER M.D., COLPRIM J. Long-term assessment of six-stacked scaled-up MFCs treating swine manure with different electrode materials. Environ. Sci.: Water Res. Technol. 3 (5), 947, 2017. https://doi.org/10.1039/ c7ew00079k.

25. OON Y.S., ONG S.A., HO L.N., WONG Y.S., OON Y.L., LEHL H.K., THUNG W.E. Long-term operation of double chambered microbial fuel cell for bio-electro denitrification. Bioprocess Biosyst. Eng. 39 (6), 893, 2016. https://doi.org/10.1007/s00449-016-1568-y.

26. ZHU G.C., CHEN G.D., YU R., LI H. WANG C.P. Enhanced simultaneous nitrification/denitrification in the biocathode of a microbial fuel cell fed with cyanobacteria solution. Process Biochem. 51 (1), 80, 2016. https://doi. org/10.1016/j.procbio.2015.11.004.

27. MICHALOPOULOS I., CHATZIKONSTANTINOU D., MATHIOUDAKIS D., VAIOPOULOS I., TREMOULI A., GEORGIOPOULOU M., PAPADOPOULOU K., LYBERATOS G. Valorization of the Liquid Fraction of a Mixture of Livestock Waste and Cheese Whey for Biogas Production Through High-rate Anaerobic Co-digestion and for Electricity Production in a Microbial Fuel Cell (MFC). Waste and Biomass Valorization. 8 (5) 1759, 2017. https://doi.org/10.1007/s12649-017-9974-1.

28. YOU S.J., ZHAO Q.L., ZHANG J.N., JIANG J.Q., ZHAO S.Q. A microbial fuel cell using permanganate as the cathodic electron acceptor. J. Power Sources. 162 (2), 1409, 2006. https://doi.org/10.1016/j.jpowsour.2006.07.063.

29. VIJAY A., VAISHNAVA M., CHHABRA M., Microbial fuel cell assisted nitrate nitrogen removal using cow manure and soil, Environ. Sci. Pollut. Res. 23, 7744-7756, 2016. https://doi.org/10.1007/s11356-015-5934-0.

30. LIN H., WU X., NELSON C., MILLER C., ZHU J. Electricity generation and nutrients removal from highstrength liquid manure by air-cathode microbial fuel cells, J. Environ. Sci. Heal. - Part A Toxic/Hazardous Subst. Environ. Eng. 51, 240-250, 2016. https://doi.org/10.1080/1 0934529.2015.1094342.

31. DOHERTY L., ZHAO X., ZHAO Y., WANG W. The effects of electrode spacing and flow direction on the performance of microbial fuel cell-constructed wetland. Ecol. Eng. 79, 8, 2015. https://doi.org/10.1016/j. ecoleng.2015.03.004.

32. LOGAN B.E., HAMELERS B., ROZENDAL R., SCHRÖDER U., KELLER J., FREGUIA S., AELTERMAN P., VERSTRAETE W., RABAEY K. Microbial fuel cells: Methodology and technology. Environ. Sci. Technol. 40 (17), 5181, 2006. https://doi. org/10.1021/es0605016.

33. DOHERTY L., ZHAO Y., ZHAO X., WANG W. Nutrient and organics removal from swine slurry with simultaneous electricity generation in an alum sludge-based constructed wetland incorporating microbial fuel cell technology, Chem. Eng. J. 266, 74-81, 2015. https://doi.org/10.1016/j. cej.2014.12.063.

34. CORBELla C., GUIVERNAU M., VIÑAS M., PUIGAGUT J. Operational, design and microbial aspects related to power production with microbial fuel cells implemented in constructed wetlands, Water Res. 84, 232242, 2015. https://doi.org/10.1016/j.watres.2015.06.005.

35. DOHERTY L., ZHAO X., ZHAO Y., WANG W. The effects of electrode spacing and flow direction on the performance of microbial fuel cell-constructed wetland, Ecol. Eng. 79, 8-14, 2015. https://doi.org/10.1016/j. ecoleng.2015.03.004. 